\title{
AGRICULTURAL AND FOOD PRODUCTION IN HUNGARY: ON THE ROAD TO SUSTAINABILITY
}

\section{Csaba Szücs ${ }^{1 *}$, Gábor Vanó ${ }^{2}$, Ferenc Korsós-Schlesser ${ }^{2}$}

'Eszterházy Károly Egyetem, Károly Róbert Campus, Gyöngyös

${ }^{2}$ Szent István Egyetem

\begin{abstract}
In the last 25 years Hungarian agriculture has lost its position. Rapid growth in the world's population requires an increase in food production since one seventh of the population is still starving. The development of agricultural production and the food industry is the basis for the development of rural areas. Hungary produces two per cent of the EU agricultural output, which is far behind its potential. Agriculture, food industry and food trade can only develop together. We need to find the most favourable forms of coexistence with multinational chains sustainably. Food industry is a critical point in the product line, it lags behind the performance of European countries, and resources are insufficient. Long-term co-operation between farmers and processors is inadequate; the common organizations of the markets are minimal. Today, sustainability is increasingly emphasized, environmental and nature protection has been appreciated. The agriculture and forestry sectors are not only suitable for production of food and other raw materials, but they can also replenish resources and have a beneficial effect on biodiversity as well. Today's problems can only be solved by taking sustainability into consideration. Agri-food industry that complies with the requirements can play a major role in rural employment and value creation.
\end{abstract}

Keywords: agribusiness, food industry, employment, sustainability, organic farming

\section{Introduction}

In our study we present the situation of agro-food industry, refer to EU data and explain the requirement of sustainability.

Despite the rapid growth in global agricultural production, the number of starving people in the world now exceeds one billion (Csáki and Jámbor, 2013; (sáki, 2012).

Over the last twenty years, food prices have risen by nearly fifty percent. The effects of climate change increase the risk of agricultural production, making food supply difficult in certain regions.

Today the food chain is an integrated network, its components include industries that provide for farmers and extract raw materials, and all the sectors that process and distribute the products (Szücs et al., 2017).

Kemény et al. (2012) refer to the role of agribusiness. According to their research, the aggregate weight of agriculture and related industries is $15.5-15.8 \%$ of output, $11.2-11.6 \%$ of the GDP, and $14.0-14.4 \%$ in employment."

We must strive for sustainable agricultural production, where we can count on the regeneration of natural resources and the assimilation capacity of the environment. Precision farming can be integrated into the sustainable management system (Csete and Láng, 2005).

\section{Material and methods}

Agri-food production is decisive in the country's economy. The state of agricultural production in Hungary is presented on the basis of KSH (Hungarian (entral Statistical Office) and Eurostat data. The statistical data is organized into tables that are suitably designed and illustrated in figures. Agricultural and food production is analysed in detail and point out the necessity, potential and importance of sustainability. A wide-ranging literature review is provided on the subject under consideration. Based mainly on secondary results, conclusions are drawn and we propose a comprehensive improvement of the situation.
Our conclusions and suggestions are aimed not only at revealing the problems, but also at determining the directions of change. Data for analysis was generally available until 2016 .

\section{Results and discussion}

Agriculture is a strategic sector. Its performance varies (depends on the weather) but has improved in recent years. Despite the improvements, our potentials are largely unutilised, mainly due to technological weaknesses and low rates of irrigation. In terms of specific output per hectare we have been doing poorly in the EU, and improving this is essential. A good part of the farmers are aging, and professional knowledge is mostly incomplete for small farmers. Domestic agriculture supplies food products, but the proportion of processed products in our exports is low. Sustainability has been improving, but organic production and precision farming have been spreading rather slowly.

\section{International outlook}

In 2016 the agricultural output of the European Union amounted to $€ 401$ billion. Hungary produced $2.1 \%$ of agricultural output of the European Union, increasing its production by $0.2 \%$ compared to the previous year (KSH, 2017). Table 1 shows data on the EU-27, main countries and Hungary.

The gross added value of agriculture has been increasing in the EU-27, but growth is significant in Hungary (Table 2).

The specific output of countries producing high value horticultural products, milk and meat is more favourable. In the Netherlands, the specific output is $€ 13.2$ thousand per hectare, while in Hungary it is $€ 1.3$ thousand per hectare. In this respect, Hungary lags behind significantly (Dupcsák et al., 2015).

In order to make data comparable, the Eurostat uses the real income indicator (indicator " $\mathrm{A}$ ") from an agricultural activity per full time worker (Table 3). Hungary's position in this respect is favourable.

For sustainability it is important to be aware of the size of organic farms. 
Table 1 Agricultural output - at basic prices * - in the main countries of the EU and in Hungary (million euro)

\begin{tabular}{|l|c|c|c|c|}
\hline & 2005 & 2010 & 2015 & 2016 \\
\hline EU-27 & 331540 & 364830 & 411761 & 398538 \\
\hline France & 64026 & 68125 & 75168 & 5187 \\
\hline Germany & 38838 & 46019 & 51239 & 52902 \\
\hline Italy & 46929 & 48160 & 55204 & 46807 \\
\hline Spain & 39599 & 40371 & 45491 & 26864 \\
\hline Netherlands & 21037 & 25319 & 26708 & 22429 \\
\hline Poland & 15052 & 19751 & 22349 & 2182 \\
\hline-- & & & & 8411 \\
\hline Slovakia & 1693 & 1887 & 8025 & \\
\hline Hungary & 6116 & 6122 & & \\
\hline
\end{tabular}

Source: Eurostat, 2017

* Output is given at basic prices. The basic price is the price producers receive after deduction of the product tax, including the amount of product subsidies. The output of agriculture includes the aggregate output of goods and services necessary to create agricultural products, services and the secondary activities inseparable from agriculture

Table 2 The gross added value of agriculture - at basic price* - in the main countries of the EU and in Hungary (million euro)

\begin{tabular}{|l|c|c|c|c|}
\hline & 2005 & 2010 & 2015 & 2016 \\
\hline EU-27 & 152012 & 150237 & 164663 & 158558 \\
\hline France & 28813 & 27862 & 29474 & 25554 \\
\hline Germany & 12812 & 14261 & 12957 & 13550 \\
\hline Italy & 28449 & 26448 & 32239 & 30065 \\
\hline Spain & 24537 & 22366 & 23995 & 25497 \\
\hline Netherlands & 8714 & 9673 & 9879 & 10260 \\
\hline Poland & 6092 & 8236 & 7857 & 8286 \\
\hline-- & 450 & & & 574 \\
\hline Slovakia & 2215 & 361 & 3254 & 3651 \\
\hline Hungary & & 1980 & & \\
\hline
\end{tabular}

Source: Eurostat, 2017

*Equals to the difference between the output (at base price) and the current production utilization when calculated on the basis of gross value added. The basic price is the producer's price after deducting product taxes, including the amount of product subsidies. The agricultural sector corresponds to sector 01 of NACE Rev. 1

Table 3 A-type indicator for agricultural income in certain EU countries* $(2010=100)$

\begin{tabular}{|l|c|c|c|c|}
\hline & $\mathbf{2 0 0 5}$ & $\mathbf{2 0 1 0}$ & $\mathbf{2 0 1 5}$ & $\mathbf{2 0 1 6}$ \\
\hline EU-27 & 81.8 & 100.0 & 109.7 & 109.2 \\
\hline France & 79.6 & 100.0 & 104.6 & 88.4 \\
\hline Germany & 84.7 & 100.0 & 78.5 & 83.0 \\
\hline Italy & 115.9 & 100.0 & 132.8 & 121.7 \\
\hline Spain & 102.8 & 100.0 & 119.9 & 125.2 \\
\hline Netherlands & 87.1 & 100.0 & 100.3 & 108.3 \\
\hline Poland & 57.1 & 100.0 & 99.4 & 100.0 \\
\hline-- & & & & 142.9 \\
\hline Slovakia & 59.3 & 100.0 & 153.0 & 173.0 \\
\hline Hungary & 82.9 & 100.0 & \\
\hline
\end{tabular}

Source: Eurostat, 2017

*Indicator " $\mathrm{A}$ " corresponds to the net agricultural added value (deflated i.e. calculated in real terms) per working unit per year. Value added is calculated at factor cost. As a defector the implicit price index of GDP is used for the calculation 
The indicator reflects the ratio of organic farming in proportion to the total agricultural area (including organic farms and farms that have not yet totally adopted organic farming during the period). Organic farming is a production method which places great emphasis on the protection of the environment and also on animal welfare in the case of animal husbandry. It avoids the use of synthetic chemicals - fertilizers, insecticides, additives, medicines - or greatly reduces the amounts used.

At the EU level, organic farming is considered a farming mode only if it complies with the Council Regulation 2092/91 and its amendment, which sets out a comprehensive framework for organic crop and livestock production, labelling, processing and marketing, and at the same time it also regulates the imports of organic products to the EU (Internet 1). The data is presented in Table 4.

Table 4 Organic farming in certain countries (\%)

\begin{tabular}{|l|c|c|c|}
\hline & 2005 & 2010 & 2015 \\
\hline EU-27 & 3.60 & 5.20 & -- \\
\hline France & 1.90 & 2.90 & 4.54 \\
\hline Germany & 4.70 & 5.90 & 6.34 \\
\hline Italy & 7.30 & 8.60 & 11.79 \\
\hline Spain & 3.10 & 6.70 & 8.24 \\
\hline Netherlands & 2.50 & 2.50 & 2.67 \\
\hline Poland & 1.00 & 3.30 & 4.03 \\
\hline-- & & & \\
\hline Slovakia & 4.60 & 9.10 & 9.47 \\
\hline Hungary & 2.20 & 2.40 & 2.43 \\
\hline
\end{tabular}

Hungary has hardly increased organic farming in the past decade, while others have made significant advances. Weak internal consumption probably also plays a role; few people can afford healthier products.

\section{The situation of the agri-food industry in Hungary}

In 2016, the share of agriculture increased significantly in investment (5.5\%) and in employment (5.0\%). The role of the food industry is also significant in investment (3.7\%) and in employment (3.3\%) in the year under review. The details are shown in Table 5 .

The emphasis on cereals and industrial crops is still decisive in the sowing structure (Figure 1).

The change of the ratio of crop and livestock production in agriculture is a serious problem. As the result of subsidies, crop production is $58 \%$ and livestock and livestock products are $34 \%$ in the total agricultural production. The share of livestock production must be increased, but this is made difficult by the fact that the lowest producer price growth was realised in this sector (Figure 2).

The situation of the food industry is worse than that of agriculture. Its profitability is low; its own resources are scarce.

The income distribution of food product lines is different, incomes in production and processing are lower, and the winner is often trade (Szücs et al., 2017). Nowadays, the food industry is beginning to shift, in almost every sector the production value is growing.

\section{Employment}

The role of the agri-food industry in rural employment is significant. Contrary to international trends, the labour demand for agriculture has increased slightly. However, aging is a serious problem, young people are reluctant to undertake work in the agricultural area, and their qualifications are poor (Kapronczai, 2016). Table 6 shows the utilization of labour in agriculture according to the Hungarian Accounting System (MSZR).

Efforts must be made and changes initiated so that the young and new generations are happy to take on work in agriculture. This can lead to increased efficiency (Farkasné Fekete et al., 2014).

The diverse forms of cooperation and partnership are indispensable, as has already been pointed out by many (Tégla et al., 2016; Hágen et al., 2016; Szabó, 2011).

Table 5 The food industry in the national economy

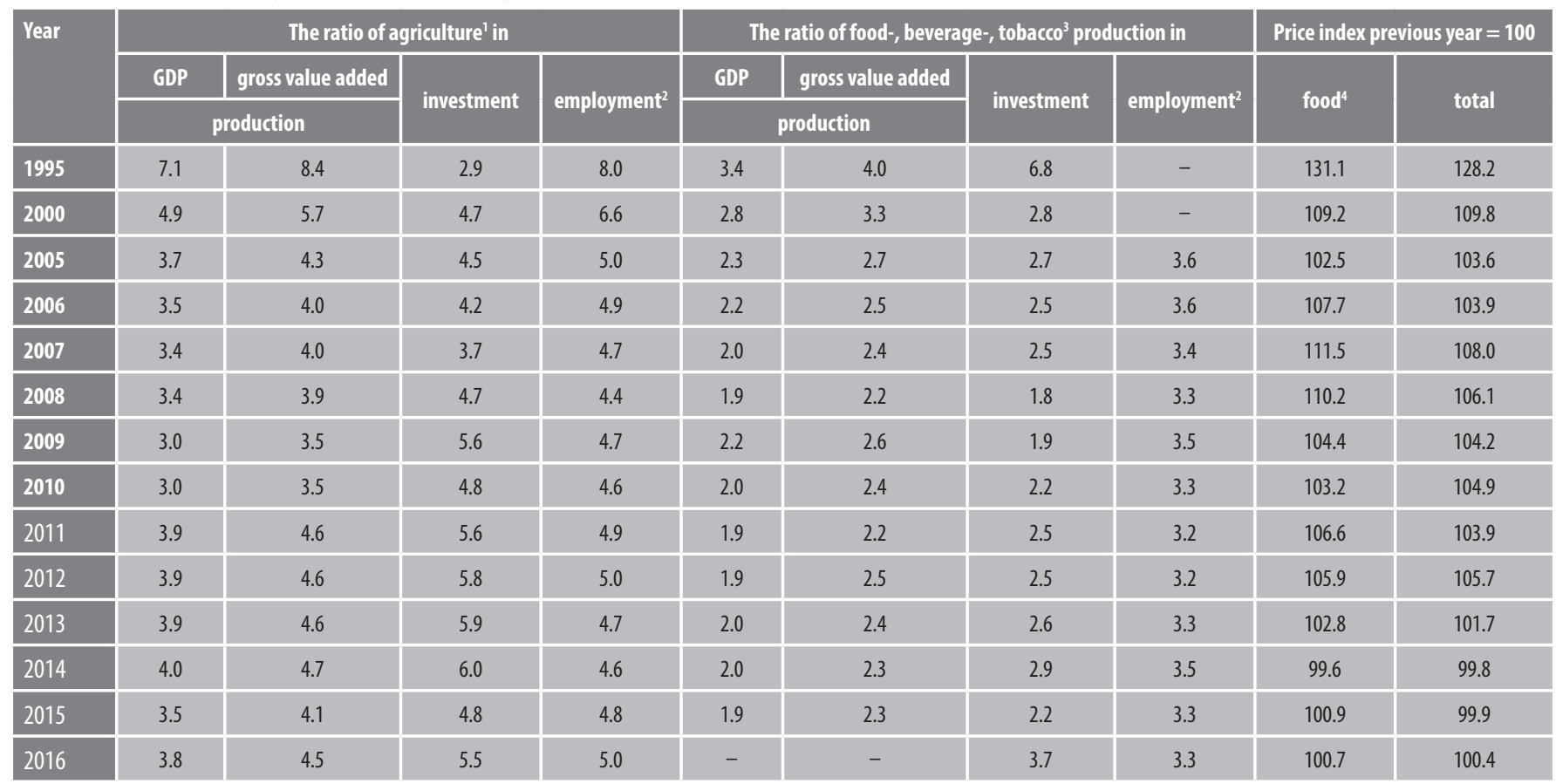

Source: KSH, AKI, 2017

1 - agriculture, forestry and fisheries, 2 - labour force survey data, 3 - businesses in the food, beverage and tobacco products sector, 4 - by product and service groups 


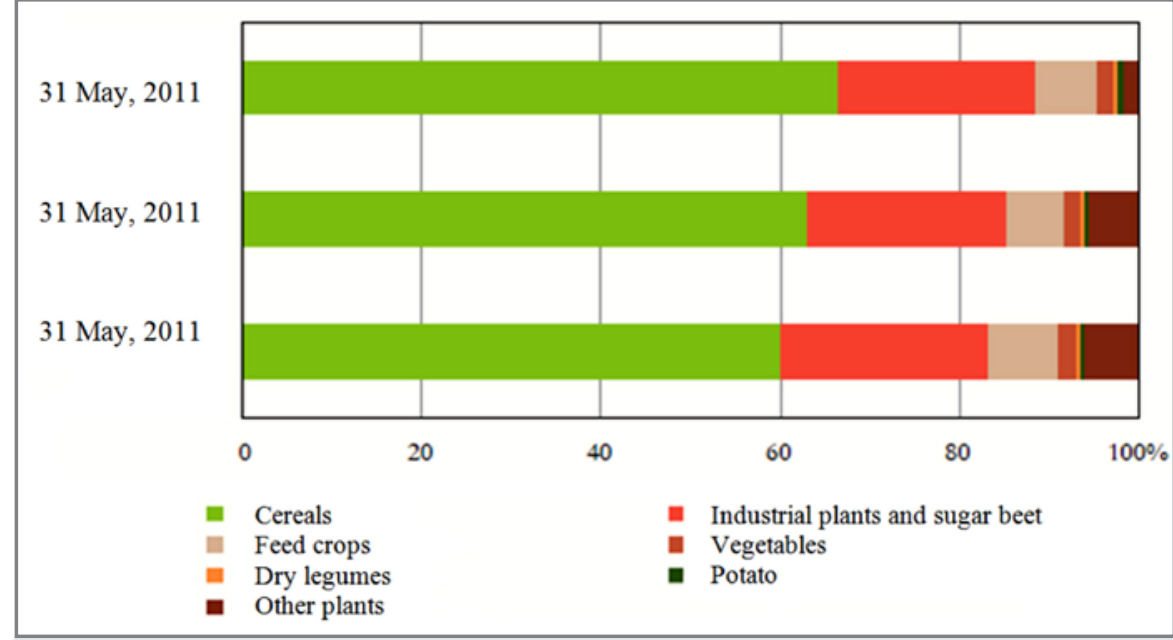

Figure 1 Sowing structure Source: KSH, 2017

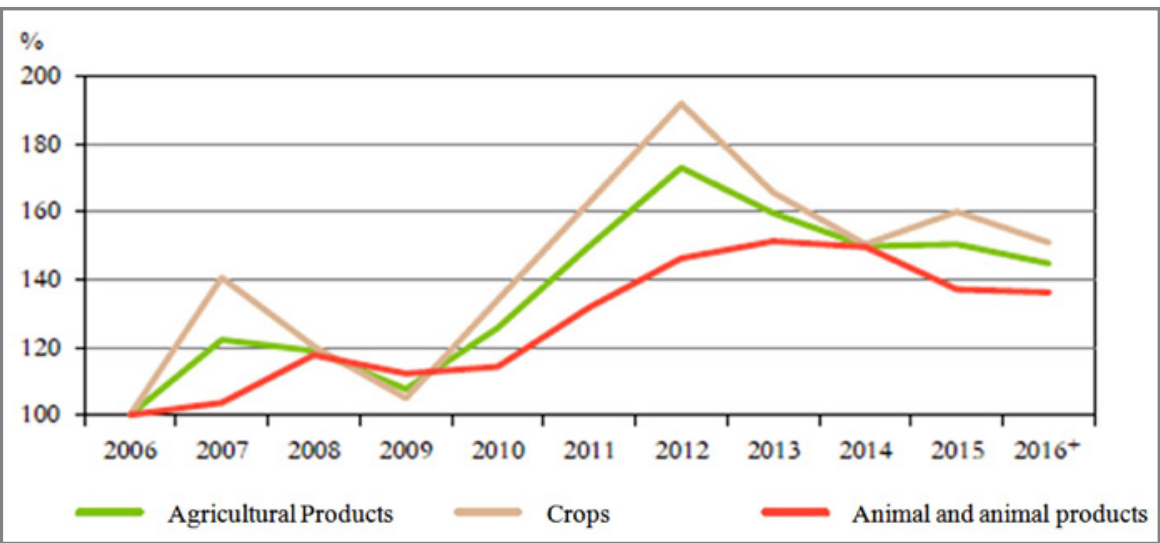

Figure 2 Producer price index of agricultural products $(2006=100 \%)$ Source: KSH, 2017

\section{Sustainable development and sustainability in agriculture}

From the perspective of the future, sustainability analysis is indispensable. We believe that our agrifood production can only be developed according to the principles of sustainability.

"Building a Sustainable Society" (Brown, 1981) was published in 1981, in which the principle of sustainable development first appeared fully. From that time on factors affecting the economy, society and the environment were addressed systematically.

The United Nations Environment and Development Committee propagated and disseminated the theory of sustainability. The committee developed a sustainable development plan under the leadership of Gro Harlem Brundtland, the Norwegian Prime Minister. The Final Report was published as "Our Common Future" (Brundtland, 1987).

Sustainable development in the interpretation of the Brundtland report is "a development that satisfies the needs of the present, without jeopardizing the ability of future generations to meet their needs".

According to the OECD Environmental Outlook (OECD 2012), the greatest challenges for both the OECD and the non-OECD countries are climate change, loss of biodiversity, unsatisfactory water resources management, and the health effects of pollution and hazardous chemicals.

Unless the principles of sustainability are met, climate change resulting from air pollution can be a serious threat. Changes can be measured by means of indicators. Sustainable agriculture and rural development are important areas for conserving natural resources.

Nowadays all economic trends address the issues of environmental regulation. The aim of environmental regulation is to comply with certain environmental quality standards, which also apply to agricultural production (Magda, 2010a).

Magda (2010b) explains that the most important issues to be addressed in sustainability include biodiversity, management of Natura 2000 sites, water and soil conservation, mitigation of climate change, including greenhouse gas reductions, ammonia emissions and, of course, the use of plant protection products that meet the requirements of sustainability.

Our world is finite; therefore, it is clear that sustainable economic growth has limitations (Mészáros, 2010). Today there are representatives of non-growth theory whose aim is to "create a society in which we live better while we work less and consume less (Latouche, 2011).

The current growth paradigms are unsustainable. This means that the world and Hungary, for the sake of sustainability, must have a green growth vision. The UN, the EU and the $\mathrm{OECD}$ play the pioneering role in the "green growth" methodology. Our goal is to achieve a synergistic relationship between economic growth and environmental protection by using less energy (Pomázi and Szabó, 2013).

Agricultural production has a significant responsibility for preserving the state of the environment and biodiversity, as agriculture is the largest user of land. It uses natural resources and is a major polluter.

Agricultural production also plays economic, environmental and social roles (Boody et al., 2005; Huang et al., 2015). Social aspects of sustainable agriculture are important factors of competitiveness (Csete and Láng, 2009). There are common elements in sustainable agriculture, such as:

$\square$ ensuring food supply in good quality,

Table 6 Agricultural labour use according to MSZR (Measurement unit: Annual Workforce Unit)

\begin{tabular}{|l|c|c|c|c|c|c|} 
& 2010 & 2011 & 2012 & 2013 & 2014 & 2015 \\
\hline Total & 444157 & 436951 & 423279 & 444424 & 462930 & 474283 \\
\hline Paid & 109176 & 108062 & 124767 & 120820 & 126766 & 128033 \\
\hline Not paid & 334981 & 328889 & 318512 & 323604 & 336165 & 346250 \\
\hline
\end{tabular}

Source: KSH, 2016 
$\square$ the preservation of the quality of the environment,

$\square$ the viability and profitability of agricultural activity,

$\square$ improving the quality of life in rural areas, social justice (Valkó, 2017).

The sustainability of agriculture can be followed by an analysis of indicators. In Hungary, Farkasné et al. (2004) and Valkó et al. (2008) played a significant role in this field. The topic is also addressed by the United Nations.

FAO's (Food and Agriculture Organization of the United Nations) SAFA system (Sustainability Assessment of Food and Agriculture Systems) established in 2013 plans to evaluate food and the effects of agricultural systems on the environment and on humans. The sales criteria are organized around four groups (FA0, 2013):

\section{$\square$ good leadership, \\ $\square$ environmental integrity, \\ $\square$ economic adaptability, \\ $\square$ social prosperity.}

Therefore, the role of the agri-food industry is extremely important in sustainability. That is why it is necessary to adhere to these principles in production.

\section{Conclusions}

The development of agricultural and food production in Hungary has recently been commendable, but it is far from its potential. Popp et al. (2008) believe that the challenges of nutrition, environmental security and sustainability require a new adaptation strategy. The decline in agricultural production would generate significant social problems. Growing horticultural production would be advisable as geothermal energy provides cheap heating in crop production and employment can be significant in this sector (Tégla and Marselek, 2007).

Magda, R. and Magda, S. (2012) see the future in increased processing, which requires strong food industry.

The issue of increasing irrigated areas has long been discussed and it is also timely to achieve results in this area.

In our country there is a significant land extracted from production; measures to reduce unused land are necessary.

Today, the principle of sustainability has been emphasized. For the future, we need to walk along this path, while respecting the regulations. Intensive co-operative development would be indispensable to improve the potentials of rural areas.

\section{References}

B00DY, G. et al. 2005. Multifuncitonal agriculture in the United States. In BioSciense, vol. 55,2005, no. 1, pp. $27-38$.

BROWN, L.R. 1981. Building a sustainable society. A Worldwatch Insitute Book. New York: W.W. Norton, 1981, $448 \mathrm{p}$.

BRUNDTLAND, G. H. et al. 1987. Our Common Future. Oxford, New York : Oxford University Press, 1987, $400 \mathrm{p}$

CSÁKI, Cs. - JÁMBOR, A. 2013. A világ mezőgazdasági és élelmezési helyzete, kihívásai. In Az élelmezésbiztonság világgazdasági dimenziói (szerk. Kiss J.) Budapest : MTA Világgazdasági Intézet, 2013, pp. 9-27.

CSÁKI, CS. 2012. Merre tart a világ mezőgazdasága? Változó prioritások a világ agrártermelésében. In (sete, L. - Fehér, I. (szerk.): A Duna két partján. Gödöllő : Szent István Egyetem, 2012, pp. 17-30.

CSETE, L. - LÁNG, I. 2005. A fenntartható agrárgazdaság és vidékfejlesztés. Budapest: MTA Társadalomkutató Központ, 2005, 313 p.

CSETE, L. - LÁNG, I. 2009. A vidék fenntartható fejlődése: a vidék fejlődésének fenntarthatósága - hétköznapi megközelítésben. Budapest: MTA Történettudományi Intézet, MTA Társadalomkutató Központ, 2009, 171 p.
DUPCSÁK, Zs. - RAGONCSA, Z. - MARSELEK, S. 2015. Kedvező változások az agrártermelésben. In Őstermelö, vol. 19, 2015, no. 4, pp. 16-21.

FA0. 2013. SAFA - Sustainability Assessment of Food and Agriculture Systems - Guidelines, Version 3.0. Rome : Food and Agriculture Organization of the United Nations, 2013, $253 p$.

FARKASNÉ, F. M. - BALYI, Zs. - SZÜCS, I. 2014. Az agrárgazdaság hatékonyságának néhány sajátos aspektusa. In Gazdálkodás, vol. 58, 2014, no. 6, pp. 564-577.

FARKASNÉ, F. M. - MOLNÁR, J. - SZÜCS, I. 2004. Fenntartható fejlödés és mérési lehetőségei a mezőgazdaságban. In Kovácsné Gaál K. (szerk.) Agrártermelés harmóniában a természettel. XXX. Óvári Tudományos Napok, Mosonmagyaróvár : Előadások és poszterek összefoglaló anyaga, 2004, október 7, 262 p.

HÁGEN, I. Zs. - MARSELEK, S. - TÉGLA, Zs. 2016. Agriculture structure in Hungary with respect to risk in crop production. In KRF. XV. Nemzetközi Tudományos Napok, Gyöngyös, 2016, pp. 631-638.

https://www.khas.hu/docs/hun/eurostat_tablak/tabl/tsdpc440.hatml 2017.09.26.

HUANG, J. et al. 2015. Comparative review of multifunctionality and ecosystem service sin sustainable agriculture. In Journal of Environmental Management, vol. 149, 2015, no. 1, pp. 138-147.

KAPRONCZAl, I. 2016. A magyar agrárgazdaság helyzete napjainkban - kockázatok és lehetőségek. In Gazdálkodás, vol. 60, 2016, no. 5, pp. 369-426.

KEMÉNY, G. - LÁMFALUSI, I. - TANÍTÓ, D. 2012. Az agrárgazdaság nemzetgazdasági szerepe az ágazati kapcsolatok mérlege alapján. In Gazdálkodás, vol. 56, 2012, no. 3, pp. 204-210.

KÖZPONTI Statisztikai Hivatal. 2016. Statisztikai Tükör: A hazai mezőgazdaság teljesítménye 2015-ben. Budapest, 2016, október 27, pp. 1-7.

KÖZPONTI Statisztikai Hivatal. 2017. A mezőgazdaság szerepe a nemzetgazdaságban 2016. Budapest, 2017, pp. 1-28.

LATOUCHE, S. 2011. A nemnövekedés diszkrét bája. Szombathely: Savaria University Press, 2011, $138 \mathrm{p}$.

MAGDA, R. 2010a. A természeti erőforrások optimális használata. In Vidékgazdaságtan I. (szerk. Magda, R. - Marselek, S.), Budapest : Szaktudás Kiadó Ház, 2010, pp. 47-78.

MAGDA, R. 2010b. Programok a jelenlegi tervezési időszakra. In Vidékgazdaságtan II. (szerk.: Magda, R. - Marselek, S.), Budapest : Szaktudás Kiadó Ház, 2010, pp. 138 161.

MAGDA, R. - MAGDA, S. 2012. A magyar mezőgazdaság és élelmiszeripar jövője. In Közgazdaság tudományos füzetek, vol. 7, 2012, no. 2, pp. 153-168.

MÉSZÁROS, S. 2010. A fenntartható fejlődést szolgáló paradigma. In Gazdálkodás, vol. 54, 2010, no. 3, pp. 275-285.

OECD. 2012. Quality franework and guidelines for OECD statistical activites. Version 2011/1, STD/QFS 2011)1, 0ECD Statistics Directorete, 2012, $69 \mathrm{p}$.

POMÁZI, I. - SZABÓ, E. 2013. A zöld növekedés mérése. In Statisztikai Szemle, vol. 91, 2013, no. 4, pp. 366-391.

POPP, J. - POTORI, N. - UDOVECZ, G. 2008. A versenyesélyek javitásának lehetőségei a főbb termékpályákon. Budapest. AKl, 2008, pp. 1-156.

SZABÓ, G. G. 2011. Szövetkezetek az élelmiszergazdaságban. Budapest : Agroinform Kiadó, 2011, pp. 1-254.

SZÜCS, CS. - VANÓ, G. - MARSELEK, S. 2017. Agrár-és élelmiszertermelés Magyarországon, várható tendenciák. In Acta Carolus Robertus: Károly Róbert Főiskola, Gazdaság- és Társadalomtudományi Kar, Tudományos közleményei, vol. 7, 2017, no. 1, pp. 11-20.

TÉGLA, Zs. - MARSELEK, S. 2007. Farm sizes in vegetable forcing. In CIOSTA Nemzetközi konferencia, Nyitra, 2007, pp. 647-654.

TÉGLA, Zs. - MARSELEK, S. - HÁGEN, I. Zs. 2016. Az agrárágazat gazdasági szerepe és jelentősége Magyarországon. In KRF. XV. Nemzetközi Tudományos Napok, Gyöngyös, 2016, pp. 1537-1544.

VALKÓ, G. 2017. A fenntartható mezőgazdaság indikátorrendszerének kialakítása az Európai Unió tagországaira vonatkozóan. Budapest : Központi Statisztikai Hivatal, 2017, pp. 1-199.

VALKÓ, G. - FEKETE, F. M. - SZÜCS, I. - MOHAMED, Zs. 2008. The Measurement of Sustainability in Agriculture. In Szűcs, I. et al. (szerk.): Economics of Sustainable Agriculture I-II. Gödöllő : Szent István University, 2008, 316 p.

\section{Contact address}

Dr Csaba Szúcs, Eszterházy Károly Egyetem, Károly Róbert Campus, Mátrai út 36, Gyöngyös, 3200, 疋 +3637518300/251, e-mail: szucs.csaba@uni-eszterhazy.hu 